\title{
Erratum to: The Soviet Hardback Revolution
}

Birgitte Beck Pristed

Erratum to:

Chapter 2 in: B.B. Pristed, The New Russian Book, New Directions in Book History, https://doi.org/10.1007//978-3-319-50708-8_2

In the original version of this chapter Table 2.1 inadvertently showed the raw data in numbers. This has now been corrected and the data is displayed in a diagram as originally intended by the author.

The updated original online version for this chapter can be found at DOI https://doi.org/10.1007//978-3-319-50708-8_2

(C) The Author(s) 2017

B.B. Pristed, The New Russian Book, New Directions in Book History, DOI 10.1007/978-3-319-50708-8_13 